\title{
Individual and Institutional Corruption in European and US Healthcare: Overview and Link of Various Corruption Typologies
}

\author{
Margit Sommersguter-Reichmann ${ }^{1}$ (D) Claudia Wild ${ }^{2} \cdot$ Adolf Stepan $^{3}$. \\ Gerhard Reichmann $^{4} \cdot$ Andrea Fried $^{5}$
}

Published online: 23 March 2018

(C) The Author(s) 2018

\begin{abstract}
In recent years, the fight against healthcare corruption has intensified. Estimates from the European Healthcare Fraud and Corruption Network calculate an approximate $€ 56$ billion annual loss to Europe as a result of corruption. To promote understanding of the complexity and interconnection of corrupt activities, we aim to present healthcare-related corruption typologies of the European Union and European Healthcare Fraud and Corruption Network. We subsequently link them to the typology of individual and institutional corruption introduced by Dennis Thompson in the context of investigating misconduct of US Congressional members. According to Thompson, individual corruption is the personal gain of individuals performing duties within an institution in exchange for nurturing private interests, while institutional corruption pertains to the failure of the institution in directing the individual's behaviour towards the achievement of the institution's primary purpose because the institutional design promotes the pursuit of individual goals. Effective anti-corruption activities not only require the enactment of anti-corruption laws but also the monitoring and, where
\end{abstract}

Margit Sommersguter-Reichmann

margit.sommersguter@uni-graz.at

1 Department of Finance, Karl-Franzens University of Graz, Graz, Austria

2 Ludwig Boltzmann Institute of Health Technology Assessment, Vienna, Austria

3 Institute of Management Science, Technical University Vienna, Vienna, Austria

4 Department of Information Science and Information Systems, Karl-Franzens University of Graz, Graz, Austria

5 Transparency International-Austrian Chapter, Vienna, Austria appropriate, revision of institutional frameworks to prevent the undermining of the primary purposes of health systems or institutions. To gain further understanding of the similarities and differences of the three typologies, prime examples of corrupt activities in the health sector in the European Union and USA (along with their potential remedies) are provided. Linking corruption cases to Thompson's typology revealed that many corrupt activities may show elements of both individual and institutional corruption because they are intertwined, partly overlap and may occur jointly. Hence, sanctioning individual actors only does not target the problem.

\section{Key Points for Decision Makers}

Different corruption typologies look at corruption from varying angles and thus help to understand the complexity of corruption and develop appropriate remedies

Many corrupt activities show elements of both individual and institutional corruption, thus remedies to combat corruption require adequate anticorruption laws and the monitoring and, if applicable, the revision of institutional settings Institutional corruption, i.e. the deviation from a standard of conduct, is hard to detect because there is no universally valid baseline as is the law for individual corruption 


\section{Introduction}

In recent years, the fight against corruption in the healthcare sector has intensified owing to the growing consensus that corruption in its various forms heavily distorts national healthcare purposes, undermines the aims of health policy measures and reforms, and leads to a tremendous waste of resources. According to recent reports on the cost of fraud in healthcare, estimates of the magnitude of corruption and social fraud range between $3 \%$ and $8 \%$ of national health expenditures $[1,2]$. In a resolution in the German Bundestag on "combating corruption in health care", a figure of up to $10 \%$ of public health expenditure was quoted [3]. In 2014 , losing $3 \%, 8 \%$ or $10 \%$ to corruption would mean, e.g. for Austria, given its health expenditures of $€ 36.3$ billion or $11.0 \%$ of gross domestic product [4], a loss of $€ 1.1$ billion, $€ 2.9$ billion or $€ 3.6$ billion. The British Centre of CounterFraud Studies examined relevant data from six countries using different methodological calculations. According to the Centre of Counter-Fraud Studies, since 2008, losses as a result of corruption have increased by $25 \%$ worldwide and even by $37 \%$ for the National Health Service in the UK [5]. For Europe, the European Healthcare Fraud and Corruption Network (EHFCN) estimates a loss of $€ 56$ billion annually $[4,6]$. Overall, European studies and estimates are rare, although the taboo nature of the topic has diminished in recent years with increasing awareness [7]. For 2010, the US Centers for Medicare and Medicaid Services estimated the loss to unnecessary or incorrect payments of approximately US $\$ 75$ billion [8]. Another study estimated the loss to the US Centers for Medicare and Medicaid Services owing to fraud and abuse at approximately US $\$ 98$ billion in 2011 [9].

Various attempts at investigating and exposing the manifold and intertwined forms of corruption have been made in addition to searching for effective ways to regulate existing corruption and potential gateways to corruption in all healthcare sectors. Transparency International [10], which is aimed at the development of definitions and categories for a better understanding of the extent, nature and impact of healthcare as well as raising awareness for corruption in healthcare, suggests five comprehensive strategies to combat corruption in healthcare. They are as follows: (1) enforcing effective anti-corruption laws; (2) improving financial management and strengthening the competences of audit courts; (3) improving access to information for the general public; (4) tightening the accountability of government; and (5) curbing opportunities to launder money from corrupt activities [11]. The Global Healthcare Anti-Fraud Network [6, 12] promotes cooperation and communication between international organisations through conferences and educational programmes. The EHFCN, which concentrates on the operationalisation and control of public institutions, has its eyes set on international awareness and transparency initiatives, organises annual conferences, and monitors and reports on corruption incidences in European Union (EU) healthcare systems [13]. The World Health Organization has launched the Good Governance for Medicines programme to combat corruption in the pharmaceutical industry [14], and the European Commission has established anti-corruption reporting mechanisms for periodic assessments of corruption in the EU [15].

Across the above-mentioned institutions and throughout the scientific literature, various definitions and concepts of corruption in general, and in healthcare in particular, have been proposed. Simultaneously, a search has been underway for remedies to combat the manifold forms of corruption. A large part of the scientific literature, however, has concentrated on individual corruption, i.e. illegal individual misconduct, such as fraud, bribery and embezzlement [7, 16-18], while recently the focus has been on those forms of corruption not necessarily illegal but nevertheless with the potential to undermine a health system's purposes and to cause a considerable waste of resources [19-23]. Investigating non-illegal forms of corruption dates back to Thompson who identified conduct on behalf of US Congressional members that " $[\ldots]$ is a necessary or even desirable part of institutional duties [...]" but "[...] has a tendency to damage the legislature of the democratic process" $[24$, p. 7]. Thompson termed this phenomenon 'institutional corruption', which he distinguished conceptually from 'individual corruption'. Institutional corruption is a situation where the institutional setting generates conflicts of interest (COI), which promotes a behaviour in those who perform the duties within the institution that systemically compromises the institution's purposes. Individual corruption is the result of personal misconduct. The term 'institutional', however, does not necessarily target a particular organisation. It may represent a superordinate system, such as the overall healthcare system, but also subsystems and single institutions, such as the pharmaceutical sector, the public hospital sector or individual hospitals.

The link with Thompson's typology is significant as existing estimates of the waste or cost of corruption are predominantly based on criminal actions, i.e. actions that fall under the category of individual corruption. However, criminally relevant corruption may well benefit from deficiencies of an institutional framework, thereby providing gateways to institutional corruption. The identification of institutional corruption, however, is particularly challenging because it is not the law but the institutional purpose that serves as the baseline for identification. In estimating the cost of corruption, the immediate costs of individual corruption (e.g. the cost of billing fraud), in addition to the 
indirect costs of legal forms of corruption have to be considered. An example of the latter may be the consequences of limitations regarding access to and the range or quality of health services; in summary, diminishing the effectiveness of the healthcare system. Therefore, the health system needs to be screened for vulnerabilities to both individual and institutional corruption and/or links between individual and institutional corruption to develop effective sanction mechanisms suitable to capture corruption complexity.

Against the background of the manifold forms and definitions of corruption, the intention of this article is to present and link recent typologies of corruption to support the operationalisation of these concepts to combat corruption in healthcare effectively. The approaches under investigation include the typologies provided by the EU, the EHFCN, and Thompson. To further support understanding of the differences and similarities of the three typologies, examples of corrupt activities in the health sector and potential remedies are provided.

This article is organised as follows: the second section is devoted to the presentation and discussion of EU, EHFCN and Thompson typologies while the third section attempts to link the typologies. The theoretical link between the various elements of each typology is complemented by real-world prime examples of corrupt behaviour and potential remedies. The article concludes with a brief summary and the main insights regarding what can be learned from the recent corruption typologies.

\section{Definitions and Typologies of Corruption in General and for the Healthcare Sector in Particular}

Transparency International, an international umbrella organisation with more than 100 national chapters, i.e. organisations combating fraud in their home countries, defined corruption in general terms as "the abuse of entrusted power for private gain. Corruption can be classified ... depending on the amounts of money lost and the sector where it occurs" [25]. Transparency International distinguishes between 'petty corruption', the everyday abuse of entrusted power by individuals, 'grand corruption', the distortion of the central functioning of the state, and 'political corruption', a manipulation of policies, institutions and rules of procedure in the allocation of resources and financing by institutions. In 2007 (and updated in 2010), the Transparency International-Austrian Chapter published a paper on "transparency deficiencies in health: gateways for corruption" [26], which promoted a categorisation according to the actors involved and identified manifold categories of actual and potential (gateways to) corrupt activities. The definitions and categories of Transparency International have been widely adopted and frequently used, for example, in audits of Austrian public institutions, such as hospital corporations [26]. By adopting Transparency International's definition of corruption, Mackey and Liang [27] developed a global health governance framework to acknowledge that national laws and institutional reforms must be internationally harmonised in terms of comprehensive international guidelines, treaty protocols and governance frameworks to effectively combat global healthcare corruption.

In recent years, the EHFCN, constituted in 2005 by the $\mathrm{EU}$, has become the pioneer in developing a typology for discriminating between error, abuse, fraud, and corruption and also between intentional and unintentional trespasses and misdemeanours in healthcare (Table 1) [28]. To support the audit and control of institutions in regard to operationalisation, the EHFCN further developed a Waste Typology Matrix ${ }^{\circledR}$ in 2014, which classifies waste according to error, abuse, fraud and corruption with respect to its consequences. The EHFCN typology is meant to be applied in operationalisation in the controlling and auditing of healthcare institutions.

In 2013, an EU report on corruption in the healthcare sector [7], which was updated in 2017 [29], clustered corrupt and fraudulent actions into six main categories of corrupt activities in healthcare (Table 2).

Thompson established institutional corruption as a new technical term to complement individual corruption (Table 3). Thompson [24, p. 28], defined corruption as "the pollution of the public by the private", which reflects the undermining of public purposes following improper services that are aimed at any gain whatsoever. Originating from this definition, Thompson identified three elements to distinguish between individual and institutional corruption: the type of the gain, the characteristics of the service, and the link between the gain and the service.

Individual corruption is related to personal gain, i.e. "goods that are usable in pursuit of one's own interest ... but are not necessary for performing one's ... role or are not essential by-products of performing the duties of that role". Institutional corruption, as is defined in the political context, refers to political gain, i.e. "goods that are usable primarily in the political process and are necessary for doing a job and are essential by-products of doing it" [24, pp. 29-30]. Personal gain as a characteristic of individual corruption is therefore beyond conventional compensation practice, while political gain, epitomising an essential element of institutional corruption, is legitimate as it is customary compensation for providing a service, which is part of the job. Political gain turns institutionally corrupt if it undermines the primary purpose(s) of the institution. 
Table 1 European Healthcare Fraud and Corruption Network (EHFCN) categories, generic definitions and examples extracted from the EHFCN Waste typology ${ }^{\circledR}[28]$

\begin{tabular}{ll}
\hline Errors & "Unjustly obtaining a benefit of any nature by unintentionally breaking a rule" \\
& Example: unintentionally billing for a service that has not been rendered \\
Abuses & "Unjustly obtaining a benefit of any nature by knowingly stretching a rule or by taking advantage of an absence of rule" \\
& Example: knowingly taking and billing a service without medical indication \\
Fraud & "Illegally obtaining a benefit of any nature by intentionally breaking a rule" \\
Corruption & "Illegally obtaining a benefit of any nature by abuse of power with third party involvement" \\
& Example: intentionally prescribing an ineffective medication to receive a kickback payment from the pharmaceutical manufacturer
\end{tabular}

Table 2 Main categories and definitions of corrupt activities according to the European Union typology [7]

\begin{tabular}{|c|c|}
\hline Categories & Definitions \\
\hline Bribery in medical service delivery & $\begin{array}{l}\text { A bribe is a financial or other advantage offered, given, solicited or accepted [95] in exchange } \\
\text { for privileges or treatments [7, p. 17] }\end{array}$ \\
\hline Procurement corruption & $\begin{array}{l}\text { Corruption of "the complete process of acquiring goods, services and works from suppliers" } \\
{[7, \text { p. 16] }}\end{array}$ \\
\hline Improper marketing relations & $\begin{array}{l}\text { "Improper marketing relations cover all interactions between the industry and healthcare } \\
\text { providers and/or regulators that are not directly linked to the procurement process." [7, p. 50] }\end{array}$ \\
\hline Misuse of (high-level) positions and networks & $\begin{array}{l}\text { "Undue high-level interactions", such as "trading in influence, revolving door corruption, } \\
\text { regulatory state capture, conflict of interest, or favouritism and nepotism" [7, p. 85] }\end{array}$ \\
\hline Undue reimbursement claims & $\begin{array}{l}\text { "Covers creative billing and reimbursement of unnecessary and non-delivered services" [7, } \\
\text { p. 89] }\end{array}$ \\
\hline $\begin{array}{l}\text { Fraud and embezzlement (of medicines, } \\
\text { medical devices and services) }\end{array}$ & $\begin{array}{l}\text { Fraud is the "offence of intentionally deceiving someone in order to gain an unfair or illegal } \\
\text { advantage" [95] } \\
\text { Embezzlement prevails "When a person holding office ... dishonestly and illegally } \\
\text { appropriates, uses or traffics the funds and goods they have been entrusted with for personal } \\
\text { enrichment or other activities" [95] }\end{array}$ \\
\hline
\end{tabular}

Table 3 Thompson typology of individual and institutional corruption and the operational definitions of Oliveira

Corruption categories and definitions

Individual corruption $\quad$ Institutional corruption

\begin{tabular}{|c|c|c|}
\hline $\begin{array}{l}\text { Thompson } \\
{[30, \text { p. 3] }}\end{array}$ & $\begin{array}{l}\text { "Occurs when an institution or its officials receive a benefit that } \\
\text { does not serve the institution and provides a service through } \\
\text { relationships external to the institution under conditions that } \\
\text { reveal a quid pro quo motive" }\end{array}$ & $\begin{array}{l}\text { "Occurs when an institution or its officials receive a benefit that } \\
\text { is directly useful to performing an institutional purpose, and } \\
\text { systematically provides a service to the benefactor under } \\
\text { conditions that tend to undermine procedures that support the } \\
\text { primary purposes of the institution" }\end{array}$ \\
\hline $\begin{array}{l}\text { Oliveira } \\
{[32,} \\
\text { p. } 11]\end{array}$ & $\begin{array}{l}\text { "Is a way for us to talk about deviations from a standard of } \\
\text { behavior, and this standard is usually offered by the law; that } \\
\text { is, it is a type of deviation that has a clear baseline for } \\
\text { analysis" }\end{array}$ & $\begin{array}{l}\text { "Is a way for us to talk about deviations from a standard of } \\
\text { operation, but we cannot count as much on the law to provide } \\
\text { us the standard, because these deviations are usually legal; } \\
\text { there is no clear baseline in this case" }\end{array}$ \\
\hline
\end{tabular}

With regard to the service, Thompson distinguishes between "its merit or its manner" [24, p. 31]. In individual corruption, the beneficiary does not deserve the service. In institutional corruption, the service is well deserved, provided within prevailing legal/institutional settings; however, "procedurally improper" (p. 33) because the legal/ institutional settings and/or customary procedures promote the benefactor's private interests rather than the institution's primary purpose(s).

By finally linking the gain with the service, another element to distinguish between individual and institutional corruption is offered. "In individual corruption ... the link 
between the gain and the service is an individual [quid pro quo; added] motive... In institutional corruption, the link is an institutional tendency", i.e. the provision of the service is independent of the benefactor's motives and provided in a systematic manner "under institutional conditions that tend to create improper influence" [24, pp. 31-32].

Thompson also referred to institutional and individual corruption as "legal and illegal corruption" [30, p. 15], while simultaneously acknowledging that the distinction between them may not always be clear, particularly as single cases may show elements of both types of corruption. This possible blur was recognised to the extent that Thompson assigned corrupt activities to individual (institutional) corruption if at least two of the three elements were individual (institutional). If, for example, the gain is personal and undeserved, but the link between the gain and the service is an institutional tendency, two of the three elements are personal so the corrupt activity is assigned to individual corruption.

Since the seminal work of Thompson, attempts have been made to create a universally valid definition of institutional corruption. Among the variety of definitions of institutional corruption provided so far [31], the operational definitions suggested by Oliveira [32] (Table 3) prove to be very useful in applying the theory of individual and institutional corruption to different settings. Oliveira first focused on the identification of a baseline, which for individual corruption is the law, and also has to be specifically defined in institutional corruption. With regard to the baseline in the context of institutional corruption, he concurred with Lessig [33] who viewed the institutional purpose as the point of reference. To get to an operational level, Oliveira [32, p. 16], proposed to interpret institutional corruption as "a situation in which the [institutional; added] design undermines the institutional purpose by making people pursue other goals". This provides a workable approach because the institutional design can be easily decomposed into a breakdown, motivation and communication structure. The breakdown structure decomposes the overall purposes into explicit and easily executable sub-goals (e.g. no one in need of care must be excluded from medical treatment). The motivation structure establishes appropriate incentives (e.g. paying different tariffs to service providers for treating insured patients differently is prohibited). The communication structure (e.g. law, regulation, rule or guideline) refers to how goals and incentives are communicated. Oliveira further focused on the differences in terms of "standard of behavior" and "standard of operation", which reflects Thompson's distinction between individual motives and institutional tendency.

Marks [34] concluded that "consensus on the definition [of institutional corruption; added] is extremely unlikely, if not impossible", thus "a set of definitions" may prove useful (p. 11). We therefore consider the various definitions provided by the EU, the EHFCN, and Thompson typologies equally appropriate to be interrelated because they complement each other, cover a wide range of corrupt activities and therefore may sharpen the view on rather disguised forms of corruption.

\section{Proposal to Link Different Typologies of Corruption}

In an attempt to highlight differences and similarities between the three typologies, we start with the EU typology, for which we provide theoretical and empirical examples of the six categories of corrupt behaviour. Then, we link the six EU categories to the categories of 'abuse', 'fraud' and 'corruption' as outlined by the EHFCN. We omit 'errors' as they represent unintentional behaviour. Finally, we examine whether the three EHFCN categories represent individual and/or institutional corruption and thus conclude by linking the EHFCN categories to the classifications defined by Thompson.

By gradually linking the three typologies (see Table 4), the EU categories can be transferred to the other two typologies. In doing so, we aim to understand the complexity and interconnections of corrupt activities. This understanding is necessary to develop appropriate instruments that combat corruption.

\subsection{Bribery in Medical Service Delivery}

Bribery is defined as a financial or other advantage that is offered, given, solicited or accepted in exchange for privileges or treatments [7, 95]. Bribery in medical service delivery frequently comes in the form of informal payments and kickback payments.

Informal payments are for services that should be provided either "free of charge or at a lower price" [7, p. 16]. According to a survey in Austria [35], 10.4\% of the patients surveyed were offered quicker access to diagnosis or treatment for cash in 2013, which is most often used to skip waiting lists. Informal payments to healthcare providers have been widespread in Central and Eastern European countries, particularly in the Ukraine, Romania, Lithuania and Hungary. Informal payments were made to receive higher quality services, increase medical staff attention and/or speed up access to healthcare services [36].

Kickback payments are a form of negotiated bribe "as a quid pro quo for services rendered" [7, p. 18], which are often inflated. The purpose is the illegitimate encouragement of bilateral cooperation by referring patients to specific services, such as radiologists, laboratories, dental 
Table 4 Links between typologies

\begin{tabular}{|c|c|c|c|}
\hline \multirow[t]{2}{*}{ European Union } & \multirow[t]{2}{*}{ European Healthcare Fraud and Corruption Network } & \multicolumn{2}{|l|}{ Corruption } \\
\hline & & Individual & Institutional \\
\hline \multirow[t]{2}{*}{ Bribery } & Fraud & Likely & Possible \\
\hline & Corruption & Likely & Possible \\
\hline \multirow[t]{3}{*}{ Procurement corruption } & Abuse & Unlikely & Likely \\
\hline & Fraud & Likely & Possible \\
\hline & Corruption & Likely & Possible \\
\hline \multirow[t]{3}{*}{ Improper marketing relations } & Abuse & Unlikely & Likely \\
\hline & Fraud & Likely & Possible \\
\hline & Corruption & Likely & Possible \\
\hline \multirow[t]{3}{*}{ Misuse of (high-level) positions and networks } & Abuse & Unlikely & Likely \\
\hline & Fraud & Likely & Possible \\
\hline & Corruption & Likely & Possible \\
\hline \multirow[t]{3}{*}{ Undue reimbursement claims } & Abuse & Unlikely & Likely \\
\hline & Fraud & Likely & Possible \\
\hline & Corruption & Likely & Possible \\
\hline \multirow[t]{3}{*}{ Fraud and embezzlement } & Abuse & Possible & Likely \\
\hline & Fraud & Likely & Possible \\
\hline & Corruption & Likely & Possible \\
\hline
\end{tabular}

technicians and hearing aid device technicians. These 'compensations' increase prices and cause millions of additional costs according to the estimates of Austrian health insurers [37].

Regarding the linking of bribery to the EHFCN typology, bribery can be related to fraud or corruption as they are both defined as illegal actions. Which offence is more likely to apply will depend on the single manifestation of bribery and the exact definitions outlined in the respective criminal code. The EHFCN defines fraud as an illegal action, which corresponds to a widely accepted definition. Thus, we can further develop the link to the concept of individual corruption because fraud requires a personal gain, an undeserved service and a quid-pro-quo motive (Table 1).

The enactment of anti-corruption laws is thus an essential step towards containing individual corruption in the health sector. In passing the Stark and Anti-Kickback laws, USA attempted to stem individual corruption in the healthcare sector. The Stark law penalises the referral of patients "to receive 'designated health services' payable by Medicare or Medicaid from entities with which the physician or an immediate family member has a financial relationship, unless an exception applies" [38]. Under the Anti-Kickback Statute, remuneration for inducing or rewarding patient referrals payable by the Federal healthcare programmes is considered a criminal act [39]. In Europe, relevant anti-corruption laws came into effect later. Although being labelled as a 'golden standard' in generic anti-corruption legislation (as opposed to the health-specific US legislation), no healthcare-related prosecutions had been reported until 2013 according to the UK Bribery Act, which came into effect in 2011 [7].

The fact that fraud can be linked to individual corruption, however, does not exclude the possibility that fraud can be considered institutional corruption. Whenever there is a dominance of institutional elements (e.g. personal gain in combination with procedurally and continuously provided inappropriate services following deficiencies in the institutional design), it would be appropriate to investigate whether the institutional design has the potential to promote illegal behaviour. The case of corruption behaves similarly to fraud. The fact that corruption is illegal links it to individual corruption, but does not exclude the link to institutional corruption. Even if the corruption examples provided by the EHFCN hint at personal gain, the institution's breakdown and incentive structure may have the potential to be procedurally improper and to promote continuously undue behaviour and thus the sanctioning of single perpetrators would not target the actual corruption problem. Gateways to institutional corruption caused by the possibility of employed public hospital physicians' engaging in dual practice (e.g. of additionally offering services as self-employed physicians in private practice or even as attending physicians in a private hospital) have been identified in Austria [40]. Although dual practice has 
been found to increase public waiting lists, leading to an overprovision of services [41,42] and promoting discrimination against socially insured patients [35], 89.7\% of medical directors and department heads of the Vienna Hospital Association indicated that they engaged in dual practice in 2006 [43, p. 15]. Institutional corruption resulting from informal payments for healthcare services has also been identified in transition countries. Although Ensor [16] chose the term 'endemic corruption' rather than 'institutional corruption' in the context of informal health payments, the characterisation of these informal payments as "part of daily life at the point at which it is no longer considered illegitimate" (p. 244) points towards institutional corruption.

\subsection{Procurement Corruption}

Procurement usually involves "large and/or long-term contracts" [7, p. 49], which distinguishes it from a mere purchasing process. The identification of technical requirements and quality specifications, the assessment of risks, and the management of the tendering process, ordering and contracting are prone to corrupt activities. Procurement corruption may take place at all stages of the procurement process and comes in diverse forms. Improper payments (bribes, kickback payments) and collusions with public officials responsible for awarding contracts, favouritism, nepotism and clientelism; bid rigging (e.g. excluding qualified bidders, unbalanced bidding, unjustified direct awards of contracts, bid suppression, market division); creation of shell companies to facilitate corruption; and submission of false, inflated or duplicated invoices are common methods of corruption in connection with procurement processes in the healthcare industry [44]. Drug procurement is considered particularly problematic because the monitoring of quality standards in drug provision is difficult and suppliers may charge different prices for the same products and induce demand for products through various marketing strategies [45]. Drug procurement corruption is seen as the main driver for the global inequalities in access to pharmaceuticals [46].

In the process of acquiring goods and services, many instances of illegitimate activities have already been identified by various Austrian audit court reports [47-50]. As a result, the public procurement processes have been regulated in recent years and additional drug and implant commissions have been implemented to reduce the bilateral exertion of influence [51]. Incidences such as favouritism (in combination with bid-price rigging and market division) and clientelism [7] in awarding contracts are rarely disclosed but still occur. By 2014, 37 countries had already participated, albeit at different phases, in the World Health Organization Good Governance for Medicines programme, of which the aim is to curb corruption in the pharmaceutical supply chain [52].

The varying forms of procurement corruption reflect deviations from a baseline. Whether the law provides the baseline or the institutional purpose has to be decided in each individual case. Consequently, procurement corruption may range from abuse and fraud to corruption as defined by the EHCFN. While fraud and corruption are typically illegal activities (which can be linked to individual or institutional corruption following the considerations outlined in the context of bribery), abuse refers to unjustly and deliberately obtaining benefits. The two decisive characteristics of abuse are the deliberate act and the lack of a clear baseline. Hence, the benefit may very well be obtained in an institutional setting, which is a grey area, i.e. where unnecessary services can be justified by giving prevailing rules an unduly broad meaning, or by entirely lacking appropriate rules.

Regarding the three distinguishing elements of individual and institutional corruption, it is rather unlikely that abuse takes the form of individual corruption on the following grounds: although the gain may be personal, the service cannot necessarily be qualified as undeserved, especially as there is often no clarity with regard to the baseline. Additionally, a quid pro quo motive is usually not the basis for the link between the motive and the service. This is different with institutional corruption: the definition of abuse as action that knowingly stretches a rule or takes advantage of missing rules perfectly fits the 'rule-following game' mentioned by Salter [53] who linked gaming, i.e. "subverting the intent of socially mandated or legislated rules for private gain without resorting to blatantly illegal acts" (p. 3) to institutional corruption. Abuse is therefore likely to come in the form of institutional corruption even if the gain is personal, particularly as gaming by subverting existing rules indicates a tendency, and service provision is procedurally improper rather than undeserved. Linking agreements for the procurement of medical devices and large equipment to the sponsoring of continuing medical education, conference attendance, reimbursement of staff costs or other add-ons in a package deal is common practice and opens gateways to institutional corruption.

\subsection{Improper Marketing Relations}

Improper marketing relations frequently occur in the context of the pharmaceutical and medical devices industry [19, 54-56]. The implementation of incentives to prescribe specific medications or to use specific products is part of the marketing strategy of manufacturers. Post-market surveillance studies that allegedly aim to gather information on the application of approved or registered medicines and therapies are often used as 'seeding trials' to introduce 
medications to the market. Physicians receive financial compensation for participating and thus, implicitly, for prescribing the monitored drug. For some expensive therapies, high financial compensations are paid to clinicians: for cost-intensive therapies (e.g. in rheumatology, ophthalmology or oncology), up to $€ 4600$ head money per patient medicated with the respective drug is paid [57]. Allegations, violations and convictions against the illegal promotion (and incentives to clinicians) and the off-label use of drugs are numerous [58]. The development of clinical guidelines or consensus reports by experts with severe COI favouring the treatment regimes of their sponsors or lowering disease thresholds has resulted in public debate in recent years.

The category of 'improper marketing relations' vividly illustrates the adverse effects of COI generation on the behaviour of service providers. If circumstances are established that enhance the risk of pursuing a secondary interest (mostly financial gain), at the expense of a primary purpose (e.g. the welfare of the patient), COI are generated. The main procedures to deal with COI are disclosure and prohibition. Prime examples of prohibition and disclosure are the 2010 US Physician Payments Sunshine Act and the Codes of Marketing Practices of the European Federation of Pharmaceutical Industries and Associations. Under the Sunshine Act, drug and device manufacturers participating in Medicare, Medicaid and the State Children's Health Insurance Program, have to disclose all financial relationships with physicians and teaching hospitals to the Centers for Medicare and Medicaid Services, who then collect and disclose this information on their Open Payments website [59]. The transparency requirements of EU directives regulating the marketing and advertising of medicines and medicinal products $[60,61]$ are reflected in the European Federation of Pharmaceutical Industries and Associations Codes of Marketing Practices [62], to which member associations voluntarily commit themselves. The regulatory requirements for post-marketing surveillance studies addressed in the European Federation of Pharmaceutical Industries and Associations Healthcare Professionals code have not yet been harmonised across Europe [62]. Austria, for example, implemented a mandatory reporting of noninterventional studies in 2010 [63], which requires the disclosure of the monitored drug, the planned structure and the number of surveyed patients, and the participating physicians and their fees to the Federal Office for Safety in Health Care. Comparable transparency regulations regarding monetary benefits paid for non-interventional studies can be found in the German Code of Conduct of the Voluntary Self-Control Association for the Pharmaceutical Industry [64].

Improper marketing relations, particularly in the context of the pharmaceutical industry, have long been regarded as a problem of inappropriate or illegal individual behaviour. Such behaviour may occur in the form of abuse, fraud or corruption as defined by the EHFCN and consequently, may appear as individual or institutional corruption as defined by Thompson. Indeed, disclosing and combating individual (illegal) corruption in the pharmaceutical industry has a long history. It has recently been recognised that a broader view in terms of reconsidering the deficiencies of the overall institutional setting, including its breakdown and incentive structure, may prove more useful in combating improper marketing relations. Gagnon [54], for example, clearly identified the practices in the pharmaceutical industry of promoting drug sales through postmarketing surveillance studies and of attempting to bypass drug approval through the promotion of off-label use of drugs, as institutional corruption.

Sponsoring continuing medical education is another feature of improper marketing relations with a considerable potential for COI. Evaluating the sponsorship of events by the industry in 13 medical fields in Austria revealed figures between $14.3 \%$ (angiology) and $67.2 \%$ (rheumatology) in 2014 [65]. In USA, the growing influence of industry on physician education resulted in the issuance of guidelines for corruption-prone interactions between academics and industry [66].

Patient groups are also targeted, or even initiated by the industry, as patient groups constitute a suitable platform for marketing measures and have the potential to exert pressure on decision makers with regard to particular treatments. A recent study on sponsoring patient groups in 2014 in Austria revealed that 136 patient groups received grants for specific projects, grassroots campaigns, patient education and other activities, totalling $€ 877,787$, which amounted to $77 \%$ of all of the declared contributions of the pharmaceutical industry [67]. Between January and June $2016,83 \%$ of 104 large US patient-advocacy organisations received contributions from the biotechnology industry and $36 \%$ reported at least one current industry executive on the governing board [68].

\subsection{Misuse of (High-Level) Positions and Networks}

The misuse of (high-level) positions and networks not only overlaps with the last two corrupt activities, it also shares their problems in case COI are generated. Conflicts of interest, however, may be individual or institutional [69], the latter being prevalent when the financial interests of the institution or its senior officials pose a risk of undue influence on the institution's primary purpose [70]. Thompson [71, p. 1], clarified that "the distinction between institutional and individual conflicts of interest is not the same as the distinction between institutional and individual corruption" because in the context of COI "the terms 
(individual/institutional) refer to the agents whose interests are in question" while in the context of corruption, "the terms refer to the forms that the influence takes". In summary, individual COI may well lead to institutional corruption.

Typical examples in the context of medical research include interactions between industry and physicians/researchers, such as the development of clinical practice guidelines or the ghostwriting of scientific articles. The most obvious and frequent example is when clinical experts taking part in sponsored research and the development of new products are probably also patent holders (see, e.g. [72]). They can then use their position as experts in committees to enforce the inclusion of new treatments and products in clinical practice guidelines and pathways by eventually lowering the access threshold [73, 74]. Ghostwriting is any undisclosed influence from industry, rather than academics receiving a small amount of assistance with their grammar and writing style. Ghost authorship exists if individuals writing the trial protocol, performing the statistical analysis or writing the manuscript are neither listed as authors nor acknowledged in the manuscript. In a study comparing clinical trial protocols provided by an ethics committee with corresponding publications reporting the results in medical journals, ghost authorship for 33 of 44 trials was identified [75]. In what follows, clinicians-owing their professional career to research grants from a manufacturer and/or to high-impact publications written by ghostwriters - are promoting new treatments or products supported by the industry as important innovations [67]. Politicians do not dare to intervene because of a fear of being denounced as rationeers; instead, they appoint leading clinicians as members of supporting committees. Last, uninformed or well-influenced journalists report on the treatments, thereby engaging public awareness while promoting marginally effective medicine [76].

Opaque interactions and networks influencing decision making regarding resource allocation, motivated by reasons other than the good of the patient, are difficult to capture. The development of guidelines to identify potential COI and the recommendation of remedies are therefore of utmost importance. A review of 100 US academic research institutions, however, revealed that only $28 \%$ had a policy dealing with institutional COI in contrast to most US medical schools that had relevant policies [77].

The misuse of (high-level) positions and networks can manifest itself in abuse, fraud or corruption as defined by the EHFCN. While offences such as fraud and corruption and individual corruption have a criminal code or other laws as a clear baseline, the misuse of (high-level) positions and networks in the form of abuse is considered a bigger problem owing to either the lack of an appropriate point of reference or the substantial scope of interpretation regarding the transposition of existing rules. Investigation of potential institutional corruption, therefore, plays a major role in this context as a missing or inconclusive baseline for an appropriate standard of behaviour that not only has considerable potential for rule-following (compliance) games, but may also signal rule-making games, i.e. "ensuring that new rules have either ambiguities or overly narrow regulations, offering rich opportunities ... to pursue innovative strategies to circumvent the rules in a murky legal environment" [54, p. 14]. The EU report on healthcare corruption has also acknowledged that the misuse of high-level positions and networks particularly "applies to institutionalised forms of healthcare corruption" [7, p. 147].

Combating lobbying (trading in influence), revolving door corruption and state capture as major forms of the misuse of (high-level) positions and networks therefore requires careful analysis of the overall institutional setting, which enables the actors to bypass and thereby corrupt primary institutional purposes. Transparency International [78] identified lobbying as "any direct or indirect communication with public officials, political decision-makers or representatives for the purposes of influencing public decision-making", which is "carried out by or on behalf of any organised group" (p. 6). Lobbying techniques range "from open participation in consultative processes to direct communications with decision-makers and the organisation of grassroots campaigns" (p. 7). Lobbying activities, however, frequently rely on "informal relationships and a variety of social interactions" (p. 7). Meanwhile, lobbying activities in Austria have concentrated on the demand rather than the supply to assert their interests, such as on price setting and the inclusion of products on lists of approved medications [7, p. 82].

The lack of compulsory cooling-off periods for lobbying institutions following changes in national leadership positions has recently become a topic in the Austrian healthcare sector. Internationally, the close (financial) link of the European Medicines Agency with the pharmaceutical industry as its main stakeholder (85\% of the European Medicines Agency's budget comes from fees "for processing applications from companies that want to bring a medicine to the market" [79]) has the potential to create COI and promote various forms of institutional corruption, such as the moving of the former executive director of the European Medicines Agency to the pharmaceutical sector [7, p. 46]. Similar concerns have been raised regarding the US equivalent, the Food and Drug Administration [55]. The main consequences are the downsizing of harmful side effects; the valuing of access to innovation higher than patient safety by inventing approval instruments of earlier market entry mostly in the interest of the pharmaceutical 
industry; and the approval of drugs with little benefit. Frequently, one act leads to another, thus lobbying, revolving door corruption and state capture are increasingly blurred.

Similarly, notified bodies (e.g. [80]) whose regulatory mandate is to assess whether a particular product meets (legally) pre-defined standards are frequently financed by contributions from the industry behind the respective product, again giving rise to potential COI. It is well acknowledged that "regulators become 'captured' by the industry they regulate, meaning that they take on the objectives of management in the firms they regulate" and that state capture is "a most destructive and intractable corruption problem" [7, p. 20].

\subsection{Undue Reimbursement Claims}

Undue reimbursement claims may occur in a variety of ways. Knowledge from sources in other countries [81] suggests that undue reimbursement claims, such as multiple billing of a single service or reimbursement claims for unnecessary interventions, are the most frequently identified causes for loss of resources. Intentionally billing services not rendered, especially for privately insured patients, can be an unofficial policy in hospitals to generate revenue. Additionally, providing procedures that lack medical indication or repeatedly providing indicated services to patients [82], without medical necessity, is especially common in patients with private health insurance. False claims, i.e. claims that show material misstatement or deceptions are considered the most obvious and central forms of fraud in the US healthcare system [83]. In 2015, $50 \%$ of US $\$ 3.5$ billion paid as a result of settlements and judgements under the False Claims Act, a law designed to combat fraud in US governmental programmes, was owing to fraud in the healthcare sector [84].

Another practice recently attracting considerable attention is the up-coding practice of service providers, i.e. the practice of charging maximum tariffs. Systematically extending the limits of Diagnosis-Related Group (DRG) coding was the reason for the 'artificial' technological progress in the Austrian hospital sector, which was identified immediately after the introduction of the DRG financing [85]. A recent study in Germany found evidence of selective up-coding regarding the birth weight of newborns, which is a major remuneration element in the German DRG-based hospital reimbursement system [86]. In USA, up-coding (defined as charging a service that was actually not used or unnecessary) and unbundling (i.e. the separate billing of bundled procedures to maximise reimbursement) were estimated to cost public medical programmes around US \$11 billion between 2002 and 2012 [87].

The billing of non-provided services clearly hints at fraud or, if a third party is involved, at corruption and further at institutional rather than individual corruption if these incidences occur systematically. However, providing proof that systematically rendered services are beyond good medical practice is challenging because of the considerable extent of medical discretion.

Legal, but undue reimbursement claims are inextricably linked to the inherent incentives. Whenever these incentives create $\mathrm{COI}$ to the extent that any secondary purposes are given priority, long-term and systemic deficiencies may arise, which hint at institutional rather than individual corruption. Further systemic COI are created when different financing mechanisms, such as fee-for-service and case fees, are combined. In Austria, systemic and faulty signalling occurs in the form of tariffs for services rendered to supplementary, i.e. privately insured, patients in public hospitals. While the tariffs of private health insurance are primarily based on fee-for-service and fee-per-day payments, public hospital financing is based on DRGs. Because the hospital and hospital doctors participate directly in the fees of private health insurance, COI are being fuelled, leading to a considerable undermining of any efficiency efforts following the introduction of the DRG financing.

\subsection{Fraud and Embezzlement (of Medicines, Medical Devices and Services)}

Fraud and embezzlement (of medicines, medical devices and services) is the last corruption typology and covers actions, such as 'sale of public or prepaid medicines for private gain'; 'sale of counterfeit medicines'; and 'use of publicly owned or financed devices or facilities for private gain' [7, p. 92]. Again, there is a considerable overlap with the previous categories as the subsequent examples illustrate. Actively involved in this category are the providers of healthcare goods and services, such as physicians, pharmacies and companies.

In Austria, invoicing gifts (natural rebates, free samples) or discounts from industry to health insurance companies; providing costly screening and diagnostic interventions in a public hospital for patients who are actually treated in a private hospital; blocking the operation theatre regularly for private patients (without refunding the hospital owner); and recruiting lucrative patients for private visitation in the public sector setting comprise the majority of reported incidents [26, 37]. Often, clinical experts with competitive avocations care for patients in public hospitals and in private institutions, thereby spending their publicly paid working time elsewhere and diverting public resources towards lucrative patients in private institutions [26]. In Romania, cases of embezzlement of publicly funded hospital medicines, which were resold (under the table) to patients or directed to parallel export, were reported [7]. 
The sale of counterfeit drugs, i.e. drugs not complying with EU intellectual and industrial property rights law [88], has become increasingly problematic owing to the extensive emergence of online pharmacies, yearning for international collaboration and increased consumer awareness [89]. As a consequence, the European Commission introduced a common logo for the websites of legally operating online pharmacies and approved retailers. In USA, initiatives to combat drug diversion, i.e. the illegal distribution or misuse of prescription drugs, have increased. The Centers for Disease Control and Prevention formally labelled drug diversion as an 'epidemic' [90]. Anti-drug diversion initiatives include enforcement activities at the individual level (e.g. physicians, nurses, patients), but increasingly involve actions at the institutional level (hospital, nursing homes, pharmacies) to increase proper oversight and diligence.

Although termed fraud and embezzlement in the EHFCN typology (hinting at illegal behaviour in the sense of individual corruption), such activities often occur in the form of abuse, i.e. without necessarily resorting to illegal acts. Such situations may arise within a legal or institutional setting that generates COI and subverts a primary purpose. Such systemic COI, potentially leading to a twotiered medical system and a considerable waste of resources, are created by the (legal) opportunity of public hospital physicians to charge fees for the treatment of supplementary (i.e. privately) insured patients in the public hospital sector in Austria [40]. Fraud and embezzlement, although collectively perceived as typically illegal acts, may therefore be indicative of even more serious problems in terms of an institutionally corrupt system.

\section{Conclusions and Lessons Learnt}

The aim of this article was to link the health-related corruption categories of the EU and EHFCN with Thompson's categories of individual and institutional corruption to show that these corruption categories, which are primarily criminally relevant (and thus represent individual corruption as defined by Thompson), may be intertwined with various disguised forms of institutional corruption. Effective anti-corruption activities therefore require not only the enactment of anti-corruption laws but also the monitoring and, where appropriate, revision of institutional frameworks to prevent the undermining of the primary purposes of health systems or facilities.

Linking three different typologies of corrupt behaviour has highlighted the following. First, many corrupt activities cannot be clearly assigned to a single category because they are very much intertwined, partly overlap and may occur jointly. The drug supply chain is a paradigm of how intertwined corrupt activities may occur. During the registration process, pharmaceutical firms have been accused of institutional corruption for having developed mainly minor-variation new drugs instead of clinically superior new drugs as a consequence of the inadequate monitoring and the commercialisation of the Food and Drug Administration [55]. The process of drug selection may be replete with kickback payments and other inappropriate payments to individuals and institutions to enable drugs to be included in national drug lists [45]. During procurement and service delivery, marketing approaches, such as undue financial compensations for the participation in postsurveillance studies or the favouring of particular treatment regimes, may generate considerable COI for individuals and institutions and lead to individual and/or institutional corruption. The awareness of the considerable overlap applies not only to single categories, but also to the three different corruption typologies. In fact, it is likely that different people make varying judgements regarding the assignment to different categories. This, however, does not reduce the benefit of any typology. It rather highlights the variety of perspectives from which corruption can be identified, thereby potentially offering further insights into corrupt behaviour.

Second, linking the EU and EHFCN typologies to the highly aggregated typology of individual and institutional corruption revealed that almost all forms of corrupt behaviour, even illegal activities, show elements of individual and institutional corruption. Therefore, only sanctioning individual actors for committing corrupt activities is far from targeting the actual problem, which makes the combating of corruption even more difficult. If the institutional setting has the potential to promote corrupt activities, significant efforts will be necessary to reduce or eliminate gateways to corruption. Relevant efforts are likely to be complicated by the cross-linked structure of health systems, their path dependence and the large number of powerful interest groups, all of whom follow their own interests. Globalisation additionally greatly increases the level of corruption complexity. In an attempt to combat various types of cross-country corruption, the United Nations Convention against Corruption, which comprises legally binding international anti-corruption agreements for United Nations Member States, came into effect in 2005 [91]. Another initiative, the United Nations Sustainable Development Goals, aims at the monitoring of global corruption by providing definitions, indicators and advocacy in combating corruption ([92] reviews indicators of Sustainable Development Goals in the context of global corruption). The United Nations recently acknowledged the devastating effect not only of individual corruption, i.e. the result of law breaking, but also from those activities "which undermine principles of medical ethics and social 
justice, as well as effective and transparent health-care provision" [93, p. 1], thereby hinting at manifold forms of institutional corruption. In addition to the enactment of anti-corruption laws, the ongoing monitoring and review of institutional frameworks of healthcare systems, institutions and associations and of global influences to combat corruption is therefore necessary.

Third, using and linking different corruption typologies also promotes the understanding of the many potentially corrupt actors that range from service providers (e.g. physicians, pharmacists or hospitals); service recipients (e.g. patients); single suppliers (e.g. pharmaceutical or medical device companies); payers (e.g. sickness funds and private health insurance companies); and regulatory bodies (e.g. European Medicines Agency, Food and Drug Administration); to entire industries, such as the pharmaceutical industry.

International and national institutions, audit courts and independent research (such as Health Technology Assessments) play an important role in combating corruption: whether it is the identification of further gateways of corruption and the raising of awareness, the definition and demarcation of corrupt activities including their operationalisation, the identification of actual corrupt behaviour, or the provision of summaries regarding the evidence of corruption. Identifying different facets of corruption is important because it simultaneously identifies instruments that can be used in the fight against corruption. These instruments range from the adaption of the legal framework to the revision of the institutional design, covering the breakdown, incentive and formalisation structure, to naming waste and overconsumption.

The EU report on corruption highlighted that combating corruption is important because "the overall impact of corruption in healthcare on society and on individuals can be significantly larger than the monetary value of the sums involved" [7, p. 29]. The impacts of corruption affecting both society and individuals range from: overpriced drugs, devices and services; low-quality medicine; unequal access to health services despite equal needs; inequality in health status between population groups; sub-optimal allocation of the healthcare budget; burden on other public budgets; market distortions; productivity loss following bad health and a brain drain of medical personnel [7, p. 29], to mention a few. Therefore, combating corruption in healthcare should be given maximum attention [94].

Acknowledgements Open access funding provided by University of Graz.

Author Contributions MSR, AS und CW conceived the idea and developed the structure of the paper. $\mathrm{CW}$ and $\mathrm{AF}$ contributed to the topic of individual corruption, while MSR, AS and GR worked on the topic of institutional corruption and the link between the corruption typologies. All authors have provided examples of individual and institutional corruption and existing and potential remedies. MSR wrote the first draft, which was then revised by $\mathrm{CW}, \mathrm{AS}, \mathrm{GR}$ and AF. All authors contributed equally to the revision of the paper and approved the final version of the manuscript prior to its submission.

\section{Compliance with Ethical Standards}

Funding Adolf Stepan was partly funded by the Brocher Foundation. The remaining co-authors did not receive any specific grant from funding agencies in the public, commercial or not-for-profit sectors.

Conflict of interest Margit Sommersguter-Reichmann (MSR), Claudia Wild (CW), Adolf Stepan (AS), Gerhard Reichmann (GR) and Andrea Fried (AF) have no conflicts of interest directly relevant to the content of this article.

Open Access This article is distributed under the terms of the Creative Commons Attribution-NonCommercial 4.0 International License (http://creativecommons.org/licenses/by-nc/4.0/), which permits any noncommercial use, distribution, and reproduction in any medium, provided you give appropriate credit to the original author(s) and the source, provide a link to the Creative Commons license, and indicate if changes were made.

\section{References}

1. Pfeil W, Prantner M. Sozialbetrug und Korruption im Gesundheitswesen (Social fraud and corruption in health care). Wien: Manz; 2013.

2. Gee J, Button M. The financial cost of healthcare fraud. Portsmouth; 2014.

3. SPD Antrag im Deutschen Bundestag. Korruption im Gesundheitswesen wirksam bekämpfen (Effectively combating corruption in health care). 2010. https://jusatpublicum.wordpress.com/ 2012/06/08/bundestag-korruption-im-gesundheitswesen/. Accessed 28 Aug 2017.

4. Hügler S. Kein Land in Europa ist immun gegen Betrug und Korruption (No country in Europe is immune to fraud and corruption). Dtsch med Wochenschr. 2010;135:33. https://doi.org/ 10.1055/s-0030-1247696.

5. Griffith R, Tengnah C. Looking at the extent of fraud within the NHS. Br J Commun Nurs. 2011;16:507-10.

6. EHFCN. EHFCN powerhouse: European Health Care Fraud and Corruption Network. 2016. https://ehfen-powerhouse.org/ welcome. Accessed 25 Jul 2016.

7. European Commission. Study on corruption in the healthcare sector: European Union. 2013. https://ec.europa.eu/home-affairs/ sites/homeaffairs/files/what-is-new/news/news/docs/20131219_ study_on_corruption_in_the_healthcare_sector_en.pdf. Accessed 4 Aug 2017.

8. Health policy brief: eliminating fraud and abuse. Health Aff. 2012. https://www.healthaffairs.org/do/10.1377/hpb20120731. 55945/full/. Accessed 18 Mar 2018.

9. Berwick D, Hackbarth A. Eliminating waste in US health care. JAMA. 2012;307:1513-6.

10. Transparency International. The global coalition against corruption. 2016. http://www.transparency.org/. Accessed 4 Aug 2017.

11. Transparency International. How to stop corruption: 5 key ingredients. 2016. https://www.transparency.org/news/feature/how_to_ stop_corruption_5_key_ingredients. Accessed 10 Mar 2016.

12. GHCAN. Global Health Care Anti-Fraud Network: Global Health Care Anti-Fraud Network. 2016. http://www.ghcan.org/. Accessed 4 Aug 2017. 
13. EHFCN. What we do. 2017. http://www.ehfen.org/who-we-are/ subpagina-twee/. Accessed 20 Dec 2017.

14. World Health Organization. Evaluation of the Good Governance for Medicines programme (2004-2012): brief summary of findings. 2013. http://www.who.int/medicines/areas/policy/goodgo vernance/1426EMP_GoodGovernanceMedicinesreport.pdf?ua=1. Accessed 15 Mar 2018.

15. European Commission. Establishing an EU anti-corruption reporting mechanism for periodic assessment ("EU anti-corruption report"). 2016. http://ec.europa.eu/dgs/home-affairs/what-we-do/ policies/pdf/com_decision_2011_3673_final_en.pdf. Accessed 4 Aug 2017.

16. Ensor T. Informal payments for health care in transition economies. Soc Sci Med. 2004;58:237-46.

17. Transparency International. Global corruption report 2006: corruption and health. 2016. https://www.transparency.org/whatwe do/publication/global_corruption_report_2006_corruption_and_ health. Accessed 15 Mar 2018.

18. Vian T. Review of corruption in the health sector: theory, methods and interventions. Health Policy Plan. 2008;23:83-94.

19. Rodwin M. Institutional corruption and the pharmaceutical policy. J Law Med Ethics. 2013;41:544-52.

20. Gøtzsche P. Tödliche Medizin und Organisierte Kriminalität (Deadly medicine and organized crime). 2nd ed. München: Riva Verlag; 2015.

21. Wilmshurst P. Institutional corruption in medicine. BMJ. 2002;325:1232-5.

22. Redman B. Are the biomedical sciences sliding toward institutional corruption? And why didn't we notice it? Edmond J Safra Center for Ethics. 2015. http://ethics.harvard.edu/workingpapers-series. Accessed 15 Aug 2017.

23. Whitaker R, Cosgrove L. Psychiatry under the influence: institutional corruption, social injury, and prescriptions for reform. New York: Palgrave Macmillan US; 2015.

24. Thompson D. Ethics in Congress: from individual to institutional corruption. Washington, DC: Brookings Institution; 1995.

25. Transparency International. FAQ: How do you define corruption? 2016. http://www.transparency.org/whoweare/organisation/faqs_ on_corruption\#defineCorruption. Accessed 25 Jul 2017.

26. Stadtrechnungshof Wien. Transparenzmängel im öffentlichen Gesundheitswesen der Gemeinde Wien (Lack of transparency in the Viennese public health system). Wien; 2009.

27. Mackey T, Liang B. Combating healthcare corruption and fraud with improved global health governance. BMC Int Health Hum Rights. 2012;12:23.

28. EHFCN. Waste typology matrix: European Healthcare Fraud and Corruption Network. 2016. https://ehfen-powerhouse.org/groups/ 4-ehfcn-waste-typology-matrix/welcome. Accessed 27 Jul 2016.

29. European Commission. Updated study on corruption in the healthcare sector: European Union. 2017. https://ec.europa.eu/ home-affairs/sites/homeaffairs/files/20170928_study_on_healthcare_ corruption_en.pdf. Accessed 11 Jan 2018.

30. Thompson D. Two concepts of corruption: Edmond J Safra Center for Ethics. 2013. http://ethics.harvard.edu/workingpapers-series. Accessed 15 Mar 2018.

31. Edmond J. Safra Center for Ethics. Working paper series: Harvard University. 2017. http://ethics.harvard.edu/working-papersseries. Accessed 26 Jul 2017.

32. Oliveira G. Institutional Corruption as a problem of institutional design: a general framework: Edmond J Safra Center for Ethics. 2014. http://ethics.harvard.edu/working-papers-series. Accessed 17 Aug 2017.

33. Lessig L. "Institutional corruption" defined. J Law Med Ethics. 2013;41:553-5.

34. Marks J. What's the big deal? The ethics of public-private partnerships related to food and health: Edmond J Safra Center for
Ethics. 2013. http://ethics.harvard.edu/working-papers-series. Accessed 28 Aug 2017.

35. Czypionka T, Kraus M, Röhrling G. Wartezeiten auf Elektivoperationen (Waiting for elective operations). Health Syst Watch. 2013;II:1-16.

36. European Commission. Assessment of patient payment policies and projection of their efficiency, equity and quality effects: the case of Central and Eastern Europe: ASSPRO CEE 2007. 2013. www.assprocee2007.com. Accessed 1 Jan 2018.

37. Transparency International-Austrian Chapter. Transparenzmängel im Gesundheitswesen: Einfallstore zur Korruption (Lack of transparency in health care: Gateways to corruption). 2010. https://www.ti-austria.at/wp-content/uploads/2016/01/ Forderungspapier-Gesundheitswesen-2010.pdf. Accessed $24 \mathrm{Jul}$ 2016.

38. Physician Self-Referral Law (Stark Law); 42 U.S.C. § 1395nn. https://www.ssa.gov/OP_Home/ssact/title18/1877.htm. Accessed 18 Mar 2018.

39. Anti-Kickback Statute; 42 U.S.C. $§ 1320 a-7 b(b)$. https://www. ssa.gov/OP_Home/ssact/title11/1128B.htm. Accessed 18 Mar 2018.

40. Sommersguter-Reichmann M, Stepan A. Hospital physician payment mechanisms in Austria: do they provide gateways to institutional corruption? Health Econ Rev. 2017;7:11.

41. Ferrinho P, van Lerberghe W, Fronteira I, Hipólito F, Biscaia A. Dual practice in the health sector: review of the evidence. Human Resour Health. 2004;2:2-14.

42. Socha K, Bech M. Physician dual practice: a review of the literature. Health Pol. 2011;102:1-7.

43. Stadtrechnungshof Wien. Nebenbeschäftigungen von Ärztinnen und Ärzten der Teilunternehmungen "Krankenanstalten der Stadt Wien" und "Pflegeheime der Stadt Wien" (Secondary occupations of Viennese hospital and nursing home physicians). Wien; 2007.

44. Heggstad K, Frøystad M. The basics of integrity in procurement. 2011. http://www.u4.no/publications/the-basics-of-integrity-inprocurement/. Accessed 14 Jan 2018.

45. Cohen J. Pharmaceuticals and corruption: a risk assessment. In: Rodriguez D, editor. Transparency International's global corruption report. London: Pluto Press; 2006. p. 77-85.

46. Fidler A, Msisha W. Governance in the pharmaceutical sector. Eurohealth. 2008;41:25-9.

47. Rechnungshof. Tätigkeitsbericht des Rechnungshofes (Activity report); Steiermark; 2004.

48. Landesrechnungshof Steiermark. Röntgenkontrastmittel und Röntgenfilme (X-ray contrast agents and X-ray films). Styria. $2005 ; 9$.

49. Stadtrechnungshof Wien. Beschaffung von EDV-Komponenten im AKH (Procurement of computer components in the AKH). Wien; 2005.

50. Rechnungshof. Kärntner Landeskrankenanstalten-Betriebsgesellschaft-KABEG (Carinthian Hospital Operating Association); Kärnten 4. 2007.

51. Bundesministerium für Gesundheit. Beiräte und Kommissionen (Advisory boards and committees): Bundesministerium für Gesundheit. 2017. http://www.bmgf.gv.at/home/Gesundheit/ Medizin/Arzneimittel/Beiraete_und_Kommissionen/. Accessed 17 Jul 2017.

52. World Health Organization. Good governance for medicines participating countries. 2014. http://www.who.int/medicines/ areas/policy/goodgovernance/progress/en/. Accessed 12 Jan 2018.

53. Salter M. Lawful but corrupt: Gaming and the problem of institutional corruption in the private sector. 2010. http://www.hbs. edu/research/pdf/11-060.pdf. Accessed 28 Aug 2017. 
54. Gagnon M. Corruption of pharmaceutical markets: addressing the misalignment of financial incentives and public health. J Law Med Ethics. 2013;41:571-80.

55. Light D, Lexchin J, Darrow J. Institutional corruption of the pharmaceuticals and the myth of safe and effective drugs. J Law Med Ethics. 2013;41:590-600.

56. Rodwin M. Reforming pharmaceutical industry-physician financial relationships: lessons from the United States, France and Japan. J Law Med Ethics. 2011;39:662-70.

57. Correctiv-Recherchen für die Gesellschaft. Euros für Ärzte (Euros for physicians): Correctiv-Recherchen für die Gesellschaft. 2016. https://correctiv.org/recherchen/euros-fuer-aerzte/. Accessed 29 Jul 2017.

58. Torjesen I. Group calls for more to be done to tackle corruption in the pharmaceutical industry. BMJ. 2016;i3099:353.

59. CMS. OpenPaymentsData.CMS.gov. 2017. https://www.cms. gov/OpenPayments/About/How-Open-Payments-Works.html. Accessed 6 Jan 2018.

60. Directive EC/2001/83 (as amended). http://www.ema.europa.eu/ docs/en_GB/document_library/Regulatory_and_procedural_guide line/2009/10/WC500004481.pdf. Accessed 18 Mar 2018.

61. Regulation EC/2004/726 (as amended). https://ec.europa.eu/ health/sites/health/files/files/eudralex/vol-1/reg_2004_726/reg_2004_ 726_en.pdf. Accessed 18 Mar 2018.

62. EFPIA. Relationships and codes. 2018. https://www.efpia.eu/ relationships-codes/. Accessed 6 Jan 2018.

63. Meldepflicht für nicht-interventionelle Studien (reporting requirements for non-interventional studies). BGBl. II 484/2012. https://www.ris.bka.gv.at/eli/bgbl/II/2012/484. Accessed 18 Mar 2018.

64. Freiwillige Selbstkontrolle für die Arzneimittelindustrie e.V. FSA Transparenzkodex (transparency code). 2015. https://www.fsapharma.de/intern/impressum/. Accessed 16 Jan 2018.

65. Ludwig Boltzmann Institute-HTA. Projekt Transparenz: Sponsoring österreichischer Ärztefortbildung (Project transparencysponsoring of physicians' continuing education). 2015. http:// eprints.hta.lbg.ac.at/1053/1/Rapid_Assessment_007a.pdf. Accessed 9 Aug 2017.

66. McMahon G. Independence from industry cannot be compromised. J Eur CME. 2017;6:3.

67. deTora L. The spectre of ghostwriting: eroding public trust in physicians, clinical trial integrity and biomedical authorship. Int J Clin Pract. 2016;70:630-3.

68. McCoy M, Carniol M, Chockley K. Conflicts of interest for patient-advocacy organizations. N Engl J Med. 2017;376:880-5.

69. Emanuel J, Steiner D. Institutional conflict of interest. N Engl J Med. 1995;26:262-7.

70. Lo B, Field M. Conflicts of interest in medical research, education, and practice. 2009. https://www.ncbi.nlm.nih.gov/books/ NBK22942/. Accessed 10 Jan 2018.

71. Thompson D. The challenge of conflict of interest in medicine. Z Evid Fortbild Qual Gesundhwes. 2009;10:136-140. http://nrs. harvard.edu/urn-3:HUL.InstRepos:10384893. Accessed 18 Mar 2018.

72. Resnik D. Institutional conflicts of interest in academic research. Sci Eng Ethics. 2015 (Epub ahead of print).

73. Lieb K, Klemperer W. Interessenskonflikte in der Medizin: Hintergründe und Lösungsmöglichkeiten. New York: Springer; 2011.

74. Norris S, Holmer H, Ogden L, Burda B. Conflict of interest in clinical practice guideline development: a systematic review. PLoS One. 2011;6(e25153):6.

75. Langdon-Neuner E. Medical ghost-writing. Mens Sana Monogr. 2008;6:257-73.
76. Wild C, Hinterreiter G. Neue Krebsmedikamente: Was ist der Fortschritt? (New cancer drugs: what is the progress?). In: Wild C, Piso B, editors. Zahlenbeispiele in der Medizin (Numerical examples in medicine). Vienna: Orac; 2010. p. 27-42.

77. Resnik D, Ariansen J, Jamal J, Kissling G. Institutional conflict of interest policies at U.S. academic research institutions. Acad Med. 2016;91:242-6.

78. Transparency International. Lobbying in Europe: hidden influence, privileged access. 2015. http://www.transparency.org/ whatwedo/publication/lobbying_in_europe. Accessed 8 Aug 2016

79. European Medicines Agency. EMA: funding. 2016. http://www. ema.europa.eu/. Accessed 8 Aug 2017.

80. Gesundheit Österreich GmbH. Österreichisches Register für Medizinprodukte (Austrian Medical Devices Registry): Gesundheit Österreich GmbH. 2016. http://www.medizinproduk teregister.at/de/benannte-stellen. Accessed 18 Aug 2017.

81. Wild C. European Healthcare Fraud and Corruption Network (EHFCN) Meeting; Eine Konferenz-Nachbesprechung (Postconference briefing). 2015.

82. Huthall K. The cost of corruption. Nurs Stand. 2010;24:18.

83. Sparrow M. Fraud in the U.S. health-care system: exposing the vulnerabilities of automated payments systems. Social Res. 2008;75:1151-80

84. Russell J. Health care tops lists of False Claims Act violations. Chicago Tribune. 2015. http://www.chicagotribune.com/ business/ct-health-fraud-tops-list-1208-biz-20151207-story,amp. html. Accessed 11 Jan 2018.

85. Sommersguter-Reichmann M. The impact of the hospital financing reform on hospital productivity: empirical evidence on efficiency and technology changes using a non-parametric inputbased Malmquist approach. Health Care Manage Sci. 2000;3:309-21.

86. Reif S, Wichert S, Wuppermann A. Is it good to be too light? The consequences of birth weight thresholds in hospital reimbursement systems. Paper presented at the EuHEA Conference, Hamburg; 2016.

87. Whistleblowers International. Upcoding: health care and Medicare fraud. 2016. https://www.whistleblowersinternational.com/. Accessed 11 Jan 2018.

88. EMA (2018) Falsified medicines. http://www.ema.europa.eu/ ema/. Accessed 11 Jan 2018.

89. Lee K, Yee S, Zaidi S, Patel R. Combating sale of counterfeit and falsified medicines online: a losing battle. Front Pharmacol. 2017;8:268.

90. Office of Inspector General. Spotlight on drug diversion. 2018. https://oig.hhs.gov/newsroom/spotlight/2013/diversion.asp. Accessed 12 Jan 2018.

91. United Nations Office on Drugs and Crime. United Nations Convention against Corruption. 2004. https://www.unodc.org/ documents/brussels/UN_Convention_Against_Corruption.pdf. Accessed 15 Jan 2018.

92. Mackey T, Kohler J, Lewis M, Vian T. Combating corruption in global health. Sci Trans Med. 2017;9(402):eaaf9547.

93. United Nations. Right of everyone to the enjoyment of the highest attainable standard of physical and mental health. 2017. http:// www.un.org/en/ga/search/view_doc.asp?symbol=A/72/137. Accessed 15 Jan 2018.

94. Gaitonde R, Oxman A, Okebukola P, Rada G. Interventions to reduce corruption in the health sector. Cochrane Database Syst Rev. 2016;16(8):CD008856.

95. Transparency International. Corruption glossary. 2016. http:// www.transparency.org/glossary. Accessed 1 Aug 2017. 